\title{
VERTICAL GARDEN UTILIZATION TRAINING FOR HIGH SCHOOL / STUDENTS IN JAKARTA
}

\author{
Inggit Musdinar Sayekti Sihing, Sri Kurniasih, Dody Kurniawan \\ Universitas Budi Luhur, Indonesia. \\ inggit.musdinar@budiluhur.ac.id
}

\begin{abstract}
The existence of open spaces in private urban villages in Jakarta is very rare. Occupancy at the center of the city causes people choose land for buildings rather than open space. Even though Jakarta has ranked in the top 5 countries with an upper threshold. Vertical garden was chosen as an alternative greening solution on limited open space. Vertical garden assistance and training is aimed at students from PGRI 15 High School located around the campus of Budi Luhur University, South Jakarta. Students are introduced to the importance of greening for environmental health and are encouraged to be creative in creating vertical garden forms with a variety of ideas. The approach method used is tri-daya, i.e. i) social power, ii) environmental power, and iii) economic power. The concept of Social Power is to invite students to become individuals who are more concerned about the environment capable of providing solutions to the completion of greening in urban areas that are increasingly limited. The concept of Environmental Power aims to invite students to take part in a residential or school environment to implement a vertical garden and increase their creativity in developing various vertical garden designs. And the concept of Economic Power is the result of the production of making vertical gardens can be used for themselves or sold to the general public, which in turn can increase the economic value of the surrounding community.
\end{abstract}

Keyword: Open Space, Vertical Garden, High School Students

\section{INTRODUCTION}

The growth of the city of Jakarta is very rapid and the decreasing amount of land in the urban villages, it is necessary to have an activity that can contribute to greening in limited land. It also builds and develops their talents and abilities towards increasing insight and creativity, so that the idea of the "Vertical Garden Utilization Training for High School Students in Jakarta" can be equipped to expand their horizons in order to prepare themselves to continue the level of higher education or the world of work that requires skills to reach a bright future. Besides that, the main objective of this training activity is to explore and enhance students' creativity in the school.

\section{Cases}

Increasingly narrow urban land reduces the presence of green open space as the lungs of the city. Even at the closest level, the dwelling house, it is rare to consider how to leave land for reforestation. Land is more maximized to answer the need for space. Therefore the purpose of this activity is: how to bring greening to a residential environment with limited land?

\section{OVERVIEW OF TARGETS}

The Vertical Garden Utilization Training is intended for state / senior high school students in South Jakarta. Precisely those who are currently in class X, XI and XII. The state high school / equivalent level that was targeted in this activity was the public high school / equivalent level around Budi Luhur University. The state high school / equivalent high school targeted for this activity are:

School Name : SMK PGRI 15 Jakarta

Address : Jalan Muchtar Raya Gg. H. Doel Rt 005 / 01jakarta Selatan, Special Region The capital of Jakarta 12260

Telephone : :(021) 58904487 


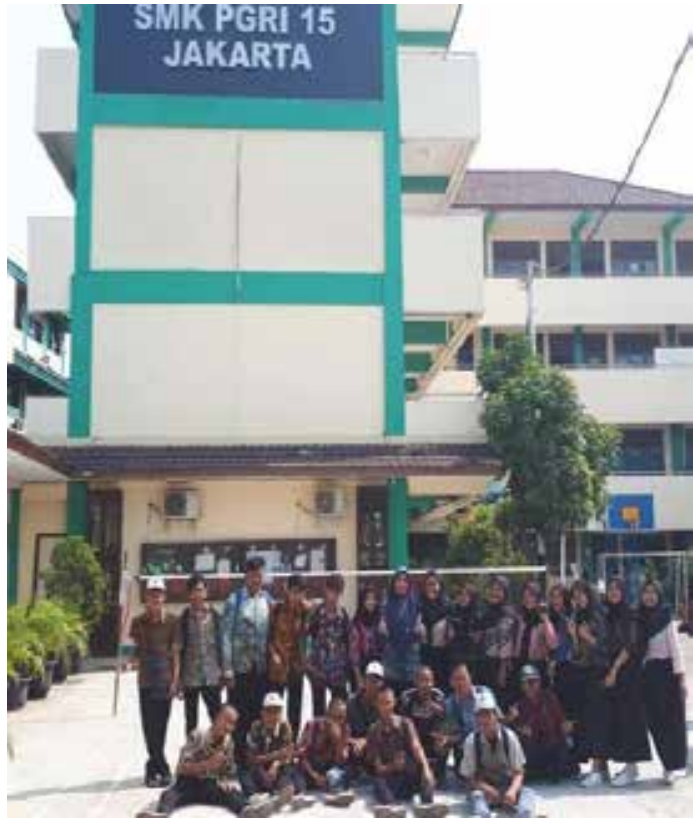

Picture 1. Target trainees

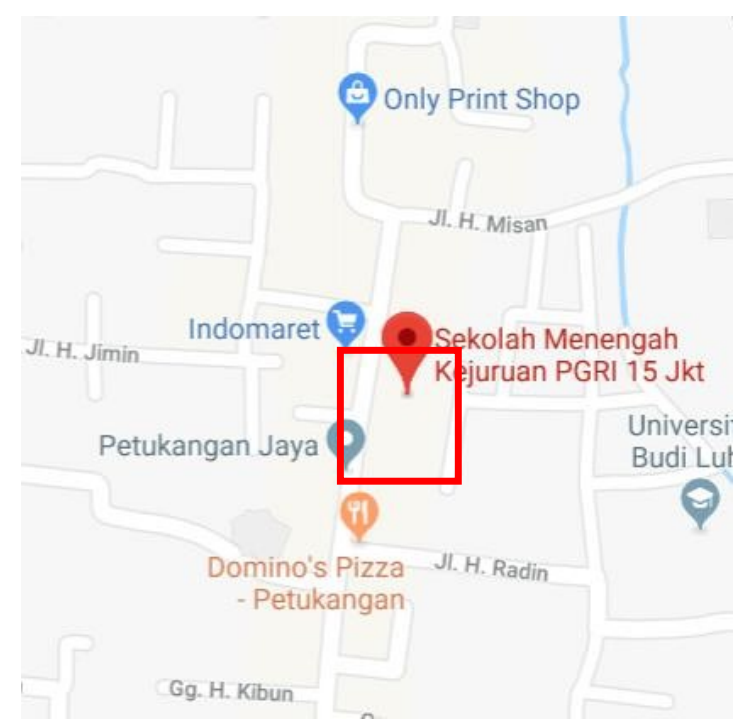

Picture 2. Map of SMK PGRI 15 Jakarta

\section{METHODS}

To go directly to the community in an effort to carry out Vertical Garden Utilization Training activities for greening high school students in Jakarta, an approach to the TRI-DAYA concept is needed.

\section{Daya Sosial}

The concept of Daya Sosial is to invite students and students through the Vertical Garden Utilization Training activities to get to know greening and then it can be applied in the home environment or in the school environment. It is hoped that students will be more concerned about the environment.

The concept of empowerment towards a generation that cares about the environment through:

a. Knowledge of the benefits of green open space.

b. Knowledge about greening on narrow land.

c. Making vertical garden as greening.

\section{Daya Lingkungan}

The concept of Daya Lingkungan is to identify:

a. The habit of the community in providing green open space for narrow land.

b. The ability of the environmental community in utilizing plants for greening.

c. The ability of the community environment to use plants as a vertical garden.

d. The ability of the community to be creative in making vertical gardens.

\section{Daya Ekonomi}

The concept of Economic Power is the result of the production of vertical gards that can be used alone or sold to the general public, which in turn can increase the economic value of the surrounding community. Moreover, it can help plant sellers in supplying plants for vertical gardens. By utilizing the vertical garden as a greening properly and correctly can give a contribution as the lungs of the city.

\section{RESULT AND DISCUSSIONS}

The stages of implementing Vertical Garden Utilization Training activities for students of SMK PGRI 15 Jakarta are as follows: 


\begin{tabular}{|c|c|c|}
\hline \multicolumn{3}{|c|}{ Monday, Januari 14 ${ }^{\mathrm{n}}, 2019$} \\
\hline $09.00-11.00$ & Surveying and licensing activities at SMK PGRI 15 Jakarta & PPM Team-FT UBL \\
\hline $11.00-13.00$ & Survey to workshop on making vertical garden mock-ups & PPM Team-FT UBL \\
\hline $13.00-14.00$ & ISHOMA & PPM Team-FT UBL \\
\hline $14.00-15.00$ & Travel to campus & PPM Team-FT UBL \\
\hline \multicolumn{3}{|c|}{ Thursday, Januari $24^{\text {th }}, 2019$} \\
\hline $09.00-10.30$ & Travel to Parung & PPM Team-FT UBL \\
\hline $10.30-12.30$ & Purchasing equipment activities & PPM Team-FT UBL \\
\hline $12.30-13.30$ & ISHOMA & PPM Team-FT UBL \\
\hline $13.30-15.30$ & Travel to campus & PPM Team-FT UBL \\
\hline \multicolumn{3}{|c|}{ Friday, Januari $25^{\text {th }} 2019$} \\
\hline $08.00-09.00$ & Travel to SMK PGRI 15 Jakarta & PPM Team-FT UBL \\
\hline $09.00-09.15$ & Preparation of activities at SMK PGRI 15 Jakarta & PPM Team-FT UBL \\
\hline $09.15-09.30$ & Opening from the school and also the PPM team & $\begin{array}{l}\text { School and PPM-FT } \\
\text { UBL Team }\end{array}$ \\
\hline $09.15-10.30$ & $\begin{array}{l}\text { Presentation about Open Space and Utilization of vertical } \\
\text { gardens for greening }\end{array}$ & PPM Team-FT UBL \\
\hline $10.30-10.50$ & Discussion and Question and Answer & $\begin{array}{l}\text { Participants and PPM } \\
\text { FT UBL Team }\end{array}$ \\
\hline $10.50-11.30$ & Workshop on making a vertical garden in the school yard & $\begin{array}{l}\text { Participants and PPM } \\
\text { FT UBL Team }\end{array}$ \\
\hline $11.30-11.45$ & Closing and a group photo & $\begin{array}{l}\text { Participants and PPM } \\
\text { FT UBL Team }\end{array}$ \\
\hline
\end{tabular}

This activity begins with the provision of material about green open space. This material is an opening ma1 and also an introduction to green open space, regulations or underlying policies. Followed by the delive: material about greening solutions in limited land, the following benefits and also the application of greeni1 the form of a vertical garden.
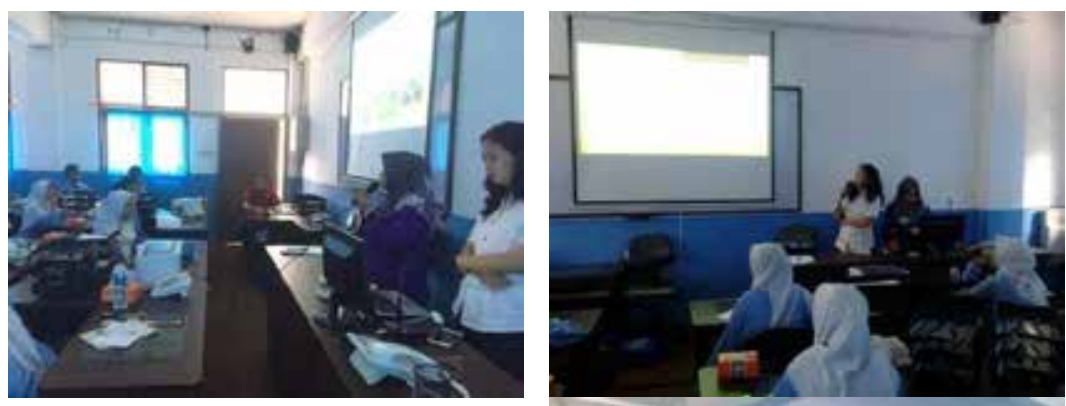

Picture 3. Presentation about open space students

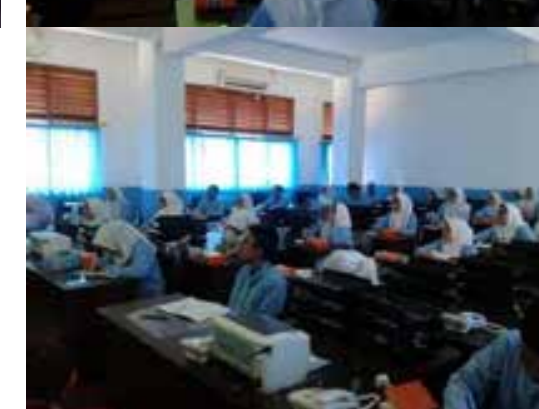

Picture 4. Presentation about vertical garden
Picture 5. The enthusiasm of the

of SMK PGRI 15 Jakarta

After the presentation session about open space and vertical garden, continued with a question and an session which was greeted enthusiastically by the students participating in the training. Then proceed making a vertical garden using the mock-ups that have been provided. The following is a documentation 0 series of training activities. 
